Published in Journal of hospitality \& tourism research, 2019, vol. 43, no. 6, pp. 867-889, which should be cited to refer to this work.

DOI : $10.1177 / 1096348019849665$

\title{
Family ownership, asset levels and firm performance in Western European hospitality companies*
}

\author{
Dr. Philippe Masset \\ Assistant Professor \\ Email: philippe.masset@ehl.ch \\ Tel: +41217851412 \\ Irena Uzelac \\ MSc student \\ Email: irena.uzelac@ehl.ch \\ Tel: +4121 7851111 \\ Dr. Jean-Philippe Weisskopf \\ Assistant Professor \\ Email: jean-philippe.weisskopf@ehl.ch \\ Tel: +41217851478
}

\begin{abstract}
All:
Ecole hôtelière de Lausanne, HES-SO // University of Applied Sciences and Arts Western Switzerland

Route de Cojonnex 18, 1000 Lausanne, Switzerland
\end{abstract}

\footnotetext{
* We would like to thank the editor and three anonymous referees for constructive feedback which greatly improved the paper. The authors acknowledge financial support by HES-SO granted under SAGE-X N³7912.
} 


\title{
Family ownership, asset levels and firm performance in Western European hospitality companies
}

This version: March 2019

\begin{abstract}
This article uses a comprehensive sample of companies from 16 Western European countries over the period 2004 and 2016 to examine the relationship between blockholder ownership, asset levels and corporate performance in the hospitality industry. We find evidence that both family and nonfamily blockholders display a higher use of assets in the lodging industry, but only non-family blockholders do in the F\&B industry. At the same time, non-family blockholders tend to display a poor performance in both industries, while this is only true for the lodging industry in the case of family-owned businesses. Finally, we show that asset levels moderate the observed ownershipperformance relationship. Our results hold both for static and dynamic asset measures and taking the Global Financial Crisis into account.
\end{abstract}

Keywords: family firm; ownership structure; performance; asset-light 


\section{INTRODUCTION}

For decades, big names have shaped the hospitality industry. Brands such as Marriott, Hilton, Hyatt, Ritz-Carlton, or Kempinski were all founded by entrepreneurs in their time. Their knowhow and visions set corporate and industry standards, influenced the performance of their respective companies and last but not least shaped the entire industry as we know it today.

Prior evidence, both from academics and practitioners (Schulze \& Gedajlovic, 2010; Sharma et al., 2012), has shown that ownership structures influence decision-making practices by management and consequently firm performance. The latter has been extensively studied over the past twenty years (Maury, 2006; Villalonga \& Amit, 2006), but the question on how exactly the differences in corporate performance can be explained and emerge remains unclear to date.

In this paper, we argue that differing asset policies among different owner types may explain a substantial part of the out- or underperformance of certain companies compared to their peers. A limited number of studies have looked into the investment behavior of companies (Anderson et al., 2012; Lee \& O'Neill, 2003) or the disposal of assets (Feldman et al., 2016; Nguyen et al., 2013) conditional on ownership. It appears that family-owned companies do not always take decisions which are purely value-driven, but may be prone to private benefit extraction (Burkart et al., 2003; Dyck \& Zingales, 2004) or emotional biases (Chrisman et al., 2003a; Habbershon et al., 2003). This may be exacerbated in the case of fixed asset expenditures or disposals (Black et al., 2003; Salzman \& Zwinkels, 2013).

The hospitality industry constitutes an ideal setting for studying the relationships between family ownership, asset intensity and corporate performance for two reasons. First, hospitality companies display a diverse set of owners. Families and entrepreneurs such as Conrad Hilton, J.W. Marriott or Berthold Kempinski had a profound influence on the entire business, whilst becoming household names to any stakeholder in the industry. Over the more recent past, institutional investors such as Colony Capital, Blackstone or 3G capital have started to gain an 
interest in the hospitality industry. This has led to an increase in merger deals and the financialization of the business. The opposition of family owners who are more conservative, long-term and service-oriented and the financial industry which is more short-term and daring makes it an ideal setting to study.

Second, over the past twenty years many hospitality managers have taken the decision to dispose of properties and to concentrate on their core business. The blend of corporations going asset-light constitutes a strong development in the hospitality industry and mixes with different owner identities, which have been present for a prolonged period of time. This makes the present case a remarkable one to analyze and yielding interesting insights going beyond the hospitality industry. The decision to remain asset-heavy or to go asset-light will be dependent on ownership structures and should have a pronounced influence on both key performance indicators and corporate policies.

Family-owned businesses may display a more emotional attachment with regard to their properties which should, overall, lead them to remain more asset-heavy. Firms owned by institutional blockholders ${ }^{1}$, on the other hand, may have more flexibility to pursue their vision and take opportunities presenting themselves on the real estate market. Finally, widely-held companies may be under pressure from financial markets to follow the general trend.

The current study aims at exploiting the unique setting that the lodging and F\&B industries offer to analyze the interrelation of family ownership with asset intensity and corporate performance. We examine a sample of 112 listed hospitality companies and 776 firm-year observations from 16 Western European countries over the period 2004 to 2016. This sample is perfectly suited for such a study thanks to its diverse ownership structures, different law characteristics, and the period covering both bullish and bearish real estate and financial

\footnotetext{
${ }^{1}$ The term blockholder is used to describe a large shareholder in a company. Following extent literature (Sraer \& Thesmar, 2007; Villalonga \& Amit, 2006) we define a blockholder as any person or group of persons (family blockholder) or entity (non-family blockholder) being the largest shareholder in a company and owning at least $20 \%$ of voting rights in it.
} 
markets. In particular, this sample allows us to investigate issues related to block holdings and family holdings that were identified by Tsai et al. (2011) as "interesting research topics in this field”.

We report four main findings. First, as could be expected, families tend to own more assetheavy companies. This is especially true in the lodging industry, but less so in the F\&B industry. This can be explained by the fact that the lodging industry requires more real estate which is generally more distinctive and thus more prone to an emotional attachment. Companies with non-family blockholders also tend to own more properties than widely-held companies. This result while not necessarily expected suggests that this type of investor perceives a minimum level of property ownership as worthwhile and important. They thus do not appear to follow the current trend on financial markets which prefer a strong focus on the core business and an asset-light structure. Second, and in line with previous evidence, the relationship between ownership structure and firm performance is unclear. In the lodging industry widely-held companies perform better while in the F\&B industry family-owned businesses outperform other firms. Third, combining asset intensity and ownership structure shows that in the lodging industry it is asset-light family businesses that display a higher profitability, but a lower valuation. In the F\&B industry being asset light is positive both in terms of ROA and Tobin's Q for family businesses. We also show that results hold if studying the disposal of fixed assets instead of asset levels and accounting for the Global Financial Crisis. Finally, we show that the hospitality industry is not uniform as findings strongly diverge for the lodging and F\&B subindustries. This shows the importance to study both sub-industries separately and to draw differentiated conclusions on their operations and performance.

This article contributes to existing literature along several dimensions. First, we clarify the relationship between owner identity and asset intensity in the hospitality industry. As noted above, research and evidence on this issue is scarce. The European hospitality industry is shaped 
by diverse ownership structures and has embarked on an asset-light strategy in recent years. It thus offers an excellent context to examine how families manage the use and disposal of fixed assets such as lodging properties and restaurants. Second, we outline the existence of a clear relation between ownership and corporate performance in the lodging and F\&B industry. Findings on this relationship in the hospitality industry is limited and mostly performed on the U.S. market (Park \& Jang, 2010; Tsai \& Gu, 2007a, 2007b). Furthermore these studies concentrate on managerial ownership which is prevalent in the United States, but does not fully reflect the European and Asian reality in which it is individuals or families and not managers owning companies. Third, we extend our knowledge on the literature on the impact of assetlight strategies. Thus far with the exception of Sohn et al. (2013), the analysis of the performance impact of asset-light structures in lodging groups is scarce. We extend this evidence by expanding the sample to the F\&B industry, studying another geographic area, and analyzing its interrelationship not only with corporate performance, but also with ownership structures. We finally contribute to a better understanding of the nuances between the $\mathrm{F} \& \mathrm{~B}$ and lodging industry. While both have some commonalities, deliver services to consumers and are often pooled together, they also display specificities and notable differences in terms of ownership structures, asset intensity, and performance.

\section{LITERATURE AND HYPOTHESES}

\section{Asset Levels and Family Ownership}

The analysis of the relation between ownership and asset intensity has not yet been performed in the hospitality industry apart from a very recent study by Kim and Jang (2018) which focuses on managerial and institutional ownership. This is surprising given the trend towards lighter asset structures that has animated this industry for the past two decades. Indeed, Praet (2013) states that "virtually nothing is known of the divestment processes in family firms 
where decisions are governed as much by financial and rational motivations as they are by the emotional forces and family traditions.”

Outside the hospitality industry, prior evidence indicates that corporate owners display diverse goals and preferences which may lead them to put pressure on corporate executives to further their personal interests (Chen et al., 2009). This is especially prominent in the presence of large shareholders who have enough power to effectively change corporate policies to best suit their objectives (Fama \& Jensen, 1985). Gompers and Lerner (2000) show evidence that even large shareholders with a short-term view may influence investment decisions to fit the company’s policies with their own interests, irrespective of minority shareholders.

Non-family blockholders may take investment decisions in two distinct ways depending on their investment horizon. Some may be invested for the longer run and will thus display a behavior similar to family-owned businesses (Jarrell \& Lehn, 1985; Wahal \& McConnell, 2000). Others, such as institutional investors, may only invest over a short period of time which will lead to short-term myopia and hamper long term investments (Porter, 1991; Thurow, 1992).

Families with their risk-aversion, conservatism and long-term approach should, therefore be at the forefront of taking corporate decisions, such as asset intensities, which ensure the longstanding survival of their firm and the alignment with their personal goals. As part of their enhanced management monitoring activity families may also constrain executives to longerterm investments to curb myopic behavior (Edmans, 2009; Stein, 1988). All of this incentivizes family-owned businesses to display a higher asset level and investment activity than widelyheld corporations. We, therefore, propose that family-owned businesses will display higher asset levels than widely-held companies due to their long-term view and emotional attachment (Feldman et al., 2016).

H10: Family firms display lower asset levels than widely-held companies. 
H1a: Family firms display higher asset levels than widely-held companies.

\section{Performance and Family Ownership}

Prior evidence of corporate performance in Western Europe has found that ownership structures are influenced by the industry (Thomsen \& Pedersen, 1998; Yuan et al., 2005). The hospitality industry has commonalities with other service industries, but its unique operational features (Chen et al., 2007) and information asymmetry that is specific to service delivery (Bergen et al., 1992) challenge the conclusions from research in other sectors or on overall markets. Research on the hospitality industry related to ownership structures and firm performance is limited, warranting the need for deeper investigation of the topic.

Only few studies have examined the effect of ownership on firm performance within different hospitality sub-sectors. ${ }^{2}$ Gu and Kim (2001) in a study on American restaurants find a positive effect of managerial ownership on restaurant performance. Park and Jang (2010) also analyze the effect of managerial ownership on restaurant performance in the United States. They indicate that performance enhancement can be achieved without the majority of votes, but that an entrenchment effect emerges at lower ownership levels in F\&B firms. Tsai and Gu (2007a) indicate a positive relationship between institutional shareholders and the Tobin's Q of U.S. restaurants. They further suggest that institutional shareholders prefer companies displaying a low leverage, good performance and larger size. Similarly, Kim et al. (2007) find that for U.S. restaurants profit margins are positively influenced by ownership structures while

\footnotetext{
${ }^{2}$ Studies outside the hospitality industry report diverging relations between firm performance and ownership structure. These notably include articles by Anderson and Reeb (2003), Fahlenbrach (2009), King and Santor (2008), Pérez-González (2006) or Villalonga and Amit (2006) in North America; Bertrand et al. (2002), Carney and Child (2013) or Claessens et al. (2000) in Asian countries and Andres (2008), Barontini and Caprio (2006), Maury (2006), Sraer and Thesmar (2007) or Thomsen and Pedersen (2000) in Europe.
} 
Im and Chung (2017) show that managerial ownership negatively affects profitability in the short-run.

Other studies have examined the lodging sub-sector. Gu and Qian (1999) address the impact of managerial ownership on performance using data on 45 U.S. lodging groups in 1996. Their results reveal that managerial ownership proxies for the convergence of interest between managers and owners resulting in improved profitability and stock returns. Based on the results from these different studies we propose that family firms will display a higher profitability and valuation.

H20: Family firms display a lower profitability than widely-held companies.

$\mathrm{H} 2_{a}$ : Family firms display a higher profitability than widely-held companies.

H30: Family firms display a lower valuation than widely-held companies.

H3a: Family firms display a higher valuation than widely-held companies.

\section{Performance, Asset Level and Ownership}

To the best of our knowledge Parrino (1997) constitutes the only study analyzing these interrelations in the hospitality industry. In his analysis on the real estate spin-off by Marriott he finds evidence that firm value was reduced and a wealth transfer occurred from debt- to shareholders. This phenomenon was further exacerbated by the expropriation behavior of the Marriott family. Both the modification in asset levels and the presence of opportunistic family members have led to a reduction in corporate value. Based on agency theory as proposed by Jensen and Meckling (1976), Cho (1998) generally shows that different owner-types will indeed chose different investment policies. This in turn should impact financial performance.

Based on the articles of Parrino (1997) and Cho (1998) and the precedent hypotheses we put two additional hypotheses forward. These should allow us to better understand the moderating 
effect different asset levels may have on the relationship between family ownership and corporate financial performance.

$\mathrm{H}_{0}$ : Family firms with high asset levels are more profitable than widely held companies.

H4a: Family firms with low asset levels are more profitable than widely held companies.

H50: Family firms with high asset levels display a higher valuation than widely held companies.

H5a: Family firms with low asset levels display a higher valuation than widely held companies.

\section{RESEARCH DESIGN}

\section{Sample}

The ownership data on publicly listed companies in the lodging and F\&B industry from 2004 to 2016 in Western Europe was collected on Bureau van Dijk. Observations with inconsistent or missing data were cross-referenced with annual reports. This dataset was augmented with accounting and market data from Worldscope. In order to avoid biases from the use of very small companies which may display erratic behavior we restrict the sample to companies with a market capitalization of at least 10 million euros and having some depth of data available in Worldscope. The companies span 16 countries which can be broken down by the prevalent source of law they belong to. According to La Porta et al. (1998) Austria, Germany and Switzerland follow German civil law, Belgium, Cyprus, France, Greece, Italy, Portugal and Spain are French civil law countries while Denmark, Finland, Norway and Sweden belong to the group of Scandinavian civil law countries. Finally, Malta and the United Kingdom use common law. The main difference between the law types emanates from the law origin with civil law grounded on statutes and ordinances, while common law is based on past judicial rulings. This has repercussions both on ownership concentration and corporate performance 
(La Porta et al., 2002; La Porta et al., 1999). The aggregation results in a total of 112 companies, yielding 776 firm-year observations. This can be broken down into 381 firm-year observations from the lodging industry and 395 from the F\&B industry and 406 firm-year observations from family firms, 148 from non-family firms and 222 from widely-held corporations.

\section{Variables}

In line with previous studies (Isakov \& Weisskopf, 2014; Sraer \& Thesmar, 2007; Villalonga \& Amit, 2006), a minimum ownership level of $20 \%$ is assumed to suffice to ensure control and define an owner as blockholder. ${ }^{3}$ If no shareholder exceeds the control threshold, the firm is considered as being widely-held. Blockholders are further separated into two groups based on identity: family if an individual or family is the ultimate owner of the company ${ }^{4}$; and other blockholders if the ultimate owner is a non-family blockholder such as the state or a financial corporation.

Asset levels can be measured in a static or dynamic manner. The former can be analyzed through the depreciation-to-sales ratio. It should display a positive relationship with the asset level of a corporation. The latter is measured as the PP\&E disposal-to-sales ratio and proxies for the periodic sale of real estate. In this case, it should negatively relate with the reduction in asset intensity by a company. ${ }^{5}$

The performance measures include Tobin's Q and return on assets (ROA) in order to analyze corporate performance from a market and accounting perspective. Tobin’s Q is estimated as the sum of market capitalization and total debt, divided by book value of total assets. ROA is computed by dividing EBIT by total assets for a given company and year.

\footnotetext{
${ }^{3}$ Due to low Annual General Meeting attendances, owning 20\% of voting rights is often sufficient to represent a majority of votes.

${ }^{4}$ A large literature studies the distinctive features of family firms and the differences between family ownership and non-family ownership on corporate policies. See for example (Chrisman et al., 2005; Chrisman et al., 2003b; Chua et al., 2003; Daily \& Dollinger, 1991; Isakov \& Weisskopf, 2014) for some evidence on the unique features of family-owned businesses.

${ }^{5}$ The European context remains fragmented with a vast majority if not all companies owning their brands.
} 
In order to control for company characteristics, control variables that are in line with existing literature are used. Firm size is calculated as the natural logarithm of total assets. The pay-out ratio is defined as the percentage of net income distributed to shareholders as dividends. Leverage is approximated by debt over (debt + equity) and sales growth is calculated as the year-on-year change in sales. Finally, all specifications contain year and law-type dummies. To restrict the potential influence of outliers on results all variables are winsorized at the $2.5 \%$ and 97.5\% levels.

\section{Methodology}

Three different specifications are used to test the three respective hypotheses on the relationships between family ownership, asset intensity and/or corporate performance.

$$
\begin{gathered}
\text { Asset level }_{i, t}=\beta_{0}+\beta\left(\text { ownership }_{i, t}\right)+\delta_{\mathrm{l}}+\delta_{\mathrm{t}}+\varepsilon_{\mathrm{i}, \mathrm{t}} \\
\text { Performance }_{i, t}=\beta_{0}+\beta\left(\text { ownership }_{i, t}\right)+\delta_{\mathrm{l}}+\delta_{\mathrm{t}}+\varepsilon_{\mathrm{i}, \mathrm{t}} \\
\text { Performance }_{i, t}=\beta_{0}+\beta\left(\text { ownership }_{i, t}\right)+\delta_{2}\left(\text { asset level }_{i, t}\right)+\delta_{1}+\delta_{\mathrm{t}}+\varepsilon_{\mathrm{i}, \mathrm{t}}
\end{gathered}
$$

where performance is ROA or Tobin's Q and asset levels depreciation or PP\&E disposal over sales. Ownership is a variable defining the different ownership measures. $\delta_{\mathrm{l}}$ and $\delta_{\mathrm{t}}$ are law type and time fixed effects. ${ }^{6}$ All specifications use firm clustered standard errors.

\footnotetext{
${ }^{6}$ All specifications were also run with the control variables presented in the variables section. We also ran specifications using country fixed effects instead of law fixed effects or with random effects. In all cases results remain qualitatively similar in both significance and magnitude.
} 


\section{EMPIRICAL RESULTS}

In this section, we report results from descriptive statistics and then test the different hypotheses described in the previous section.

\section{Descriptive statistics}

Figure 1 plots cumulative frequencies for asset intensity (depreciation over sales) for different subsamples. The upper left panel indicates that F\&B companies are on average more asset light than is the case for lodging groups. In the upper right panel we observe that it is widely-held companies which tend to be more asset light while companies with non-family blockholders and family firms remain more asset intensive. Finally, in the bottom two panels we cross industry with owner-type and find evidence that results are diverging. Widely-held lodging groups are asset light, while family and other blockholders are asset heavy and show an essentially identical distribution in the lodging industry. In the F\&B industry the picture is different with an essentially identical distribution for all owners up to a cumulative frequency of $70 \%$. Then, while family and widely held F\&B groups continue to display similar distributions it is companies with non-family blockholders which are more asset heavy.

\section{[Insert Figure 1 here]}

Expanding results from Figure 1, Table 1 shows descriptive statistics and univariate tests per industry (lodging and F\&B) and owner-type. On average, hospitality companies in Western Europe have 367 million Euro of total assets. Leverage stands, on average, at 42\%, the pay-out ratio at $48 \%$ and sales growth at $9 \%$ p.a. In terms of performance, average Tobin's Q is 1.17 and ROA 5.48\%. Finally, companies depreciate $6.26 \%$ and sell assets for $4.97 \%$ of their sales.

Turning to univariate tests two interesting facts appear. First, both family firms and those with a non-family blockholder operate with significantly more assets and are less inclined to 
part with them through time. This tendency is much more pronounced for the lodging than the F\&B industry. This is in line with the general debate on asset lightness being more concentrated in lodging companies and the argument that families are more emotionally attached to their assets which hinders them to shed them. Concerning market and accounting performance it appears that family firms significantly underperform widely-held companies in the lodging industry, but much less so in the F\&B industry. This result is even more marked for companies with a non-family blockholder. This result can be explained by the stronger use of assets and thus of capital by both shareholder types which depresses corporate performance.

\section{[Insert Table 1 here]}

Control variables are in line with previous literature. Companies with a blockholder tend to be smaller in size, grow less and are less indebted. The pay-out ratio is also smaller for companies with a blockholder. This could be explained by the asset- and capital-heavy characteristic of the industry in which companies want to keep a financing margin without having to resort to capital markets which may be unattainable at times. Alternatively, and following Villalonga and Amit (2006), family firms manage debt and dividends differently. Family firms have significantly lower leverage and pay-out ratios than non-family firms. These findings suggest that the capital structure and payout policy allow for easier expropriation of minority shareholders by maintaining corporate wealth in the hands of individual controlling shareholders (Faccio et al., 2001; Jensen, 1986). This could subsequently contribute to lower firm valuation and goes hand in hand with the smaller company size, low indebtedness and Tobin’s Q of blockholder-owned companies.

The different observations drawn from the univariate tests call for a more in-depth analysis of the asset use of hospitality companies and the performance of these companies. Both 
ownership structures and industry type appear to strongly moderate the general outcome observed in prior literature on asset levels and performance.

\section{Family ownership and asset levels}

Table 2 displays findings on the relationship between asset intensity and ownership structure. They confirm results from univariate tests. Family-owned businesses have a tendency to own more assets in the lodging industry, but much less so in the F\&B industry. This relation exists as soon as a family is present in the company, independently of the stake it owns. This may be explained by the fact that asset structure represents an important corporate decision which the family may decide upon irrespective of the stake it owns. Companies with non-family blockholders also remain more asset heavy not only in the lodging, but also in the F\&B industry. Therefore, hypothesis $\mathrm{H} 1_{0}$ is rejected.

[Insert Table 2 here]

\section{Family ownership and financial performance}

Table 3 indicates results on the relationship between ownership structure and financial performance measured by ROA and Tobin’s Q. Once again we find that industry and ownership structure significantly moderate findings. In the lodging industry both family and non-family blockholders lead to a significantly poorer accounting performance. In the F\&B industry this is, however, only verified for non-family blockholder companies while family firms insignificantly outperform widely-held companies. Tobin’s Q also leads to diverging results. In this case, non-family blockholder companies once again underperform in both industries. Family companies, on the other hand, significantly underperform in the lodging industry but significantly over-perform in the F\&B industry. 
[Insert Table 3 here]

This conflictual finding may be explained by the specificities of these two industries. Lodging companies have a stronger need for assets and families tend to hang on to these assets which may lead to a poorer accounting and market performance. Therefore, hypotheses $\mathrm{H} 2_{0}$ and $\mathrm{H}_{0}$ cannot be rejected in the lodging industry only, while they are rejected in the $\mathrm{F} \& \mathrm{~B}$ industry.

\section{Family ownership, asset level and financial performance}

In Table 4 and 5 we extend results from the two previous sub-sections to gain a better understanding of the cross-relationship between ownership structure, asset intensity and financial performance.

Accounting performance is negatively affected by asset intensity. The inclusion of this variable in our specification thus reduces the influence exerted by the family firm dummy on ROA. This suggests that part of the negative performance of family firms is due to their more asset heavy character as compared to widely-held companies. This holds true both for the lodging and F\&B industry. For Tobin’s Q the relationship appears the opposite for lodging in which companies displaying a higher asset intensity have a higher market performance. For the F\&B industry we observe no change. Generally, this effect may explain a premium on “substance” which diminishes risks of lodging companies owning their walls.

[Insert Table 4 \& 5 here]

We further investigate this distinction by creating two dummies for observations which display an above or below median asset intensity. We then interact these with the ownership variables. We confirm the initial evidence that for the ROA family firms with low asset 
intensities outperform those with higher asset intensities. For Tobin's Q results depend on the sub-industry. For hotels asset heavy family firms continue to perform better, while in the F\&B industry asset lightness is key to performance. These observations are generally also correct for non-family blockholder companies with better accounting but worse market performance. Therefore, hypothesis $\mathrm{H}_{4}$ cannot be rejected, while $\mathrm{H} 5_{0}$ is rejected.

\section{Extensions to the analysis}

We extend the baseline results with two additional analyses. First, we run all specifications on a dynamic asset intensity variable (PP\&E disposal over sales). Second, we take a closer look at the Global Financial Crisis (GFC).

So far we have analyzed how static asset levels relate to ownership structures and financial performance. However, companies generally do not remain at a given level of assets but especially in the last two decades have shed a large part of their properties to become increasingly asset-light (Sohn et al., 2013). We therefore redo all calculations on a dynamic asset variable which consists of PP\&E disposal over sales. This allows us to gain a deeper understanding on the effect the process of turning asset-light has.

Results indicate that lodging companies with a blockholder (family and non-family) sell significantly less assets than widely-held corporations. This is also the case in the F\&B industry, but only insignificantly. Contrary to the static measure family stake appears to have an impact in this case. Companies with a majority family shareholder reduce their assets twice less than those with a stake between 20 and 50\%. Considering results in Table 4 and 5 we find that the use of a dynamic or static asset intensity variable leads to very similar results.

The GFC can be considered a specific period which may affect findings on the overall sample. It had a strong impact on real estate markets which may have led to specific outcomes in terms of asset intensity choices and possibilities to modify it. It further made financing more constraining or downright impossible for some companies. Finally, it had an impact on financial 
performance which may have modified the behavior of companies dependent, amongst others, on their ownership structure (Lins et al., 2013).

Overall, and as expected, we find that the average and median ROA and Tobin’s Q dropped significantly during the GFC. However, while the ROA quickly rebounded (around 2010) it took longer for Tobin’s Q (around 2014). Turning to the analysis presented thus far but omitting the GFC we find that the relationship between asset intensity and ownership structure is not impacted. It therefore appears that both the static and dynamic asset intensity remains rather constant including the GFC or not in the sample. Overall, this also holds true for the performance measures. The relationship between ownership structure and financial performance remains equivalent to the sample including the GFC suggesting that companies were equally affected by the crisis irrespective of ownership structures. More specifically, both Tobin's Q and ROA coefficients remain qualitatively similar but for family-led hotels now displaying a ROA which is slightly lower and family-led F\&B outlets a somewhat higher ROA. This indicates that they did relatively better respectively worse during the GFC than their nonfamily counterparts. Findings on the relationship between asset intensity, ownership structure and performance tend to become more pronounced omitting the GFC. This may be explained by the strong performance fluctuations during the GFC which affected the coefficients and their significance. More specifically, we find a clear and significant negative relation between asset intensity and profitability. The relation with Tobin's Q is generally positive, but not always significant. We further find evidence of a strong negative respectively positive relationship between family ownership and performance in the lodging and F\&B business. Finally, companies with non-family blockholders always do worse than widely-held and family-owned corporations. 


\section{CONCLUSION}

\section{Managerial implications}

Families have their own personal ways of running their businesses. While they are not philanthropists and want to enjoy the benefits of the cash their company can generate many are also in the pursuit of something more. This can take different forms such as private benefits, pride in having the family name and reputation being disseminated in public or simply perpetuating the family legacy. This has important implications for outside managers and investors who need not only to understand the inner working of the company but also of the family owning it. This in turn has an impact on the corporate policies and performance of these companies and as shown in this study may lead to poor, but also to positive outcomes for shareholders depending on how the family is managing the firm.

Having a family on-board is often perceived as detrimental and is met with skepticism. For example, upon the nomination of Mr. Pélisson (the nephew and heir of one of Accor's founders) as Chairman and CEO of Accor questions were asked on his qualifications and doubts of nepotism arose. However, he moved Accor forward and embarked it, if not in an asset-light, at least in an asset-right direction. Our study shows that on average family groups tend to be more asset-heavy and to hang on to their real estate. This, as in the case of Accor, may lead to conflicts with non-family shareholders. While finding the optimal asset level is generally no small feat it is even more difficult inside family-owned corporations who follow non-pecuniary benefits. However, this may also unlock value if an inefficient asset allocation is directing towards a more optimal level through time. It is thus important to understand the interrelationship of families with firm management and minority or institutional investors. In the case families are flexible enough and do not entrench themselves this may lead to positive outcomes for investors. Not only may the financial knowledge of outside managers and institutional investors 
help the family, but the deep knowledge and long term view of the family may help outside shareholders to unlock value.

\section{Future research}

Our contributions open up interesting venues for future research. Even though we use a time frame of more than a decade spanning periods of economic expansions and strong turmoil a longer time period would allow for more cross-time stability of our results in terms of business and real estate lifecycles. Especially the decision to embark into an asset-light process or building up a hotel group and their implementations take time and can have impact on performance in the longer run which we cannot measure as of now due to the late start of European hospitality companies into the asset-light arena. It would also allow us to gain a deeper understanding of the sticky evolution of ownership structures and the concentration process taking place in the sector over the last decades and to analyze how changes in ownership impact corporate policies and performance.

Our study concentrates on the European market and shows that family owners do have an impact on both corporate investments and performance. While the U.S. market has strongly shifted towards an asset-light model this is less the case in Europe due to its more traditional approach and its family ownership as shown in this study. It would, therefore, be interesting to extend the validity of the study to emerging hospitality markets such as Asia, Africa or Latin America in which family ownership has also been shown to be prevalent (Carney \& Child, 2013; Gonzalez et al., 2017). At the same time, these markets orient themselves more towards U.S. business practices while their financial development does not always allow them to fully make use of an asset-light strategy.

Finally, the ways through which a family can influence and shape its business are vast (Astrachan et al., 2002) and still not well understood today. We have analyzed the holdings of voting rights but a family could exert power through management positions or indirect influence 
on outside investors or managers. With the development of better databases it may be possible to examine how exactly families shape their businesses and differentiate them from corporations with other ownership structures. This would allow us to observe and describe the many interrelationships of family capitalism inside the hospitality industry.

\section{Summary}

Family ownership has been observed as a common control structure outside Anglo-Saxon markets. However, research on this subject in the hospitality industry is highly limited. This study thus contributes to the literature by examining their effect on hospitality companies in Western Europe. More specifically, we analyze the interrelation between ownership structure, asset intensity and their effect on corporate financial performance. Overall, we report novel insights to theory along three dimensions. First, we contribute to extent but limited research on the relationship between performance and ownership structures in the hospitality industry. Second, we study the link between owner-type and asset levels which has not yet been done in the hospitality industry. Third, we extend our knowledge on the literature on the impact of assetlight strategies which is also relatively scarce in the hospitality industry. Finally, we put a special emphasis on different asset variables, the Global Financial Crisis and specificities of the lodging and F\&B industry.

We find evidence of a significantly positive relationship between ownership and asset intensity. This is especially the case for families in the lodging industry and for non-family blockholders in both the lodging and F\&B industry. We also show that non-family blockholders lead to an underperformance in both industries in terms of accounting and market performance. For family-owned businesses performance is lower in the lodging, but stronger in the $\mathrm{F} \& \mathrm{~B}$ industry as compared to widely-held companies. Combining asset intensity and ownership structure shows that in the lodging industry it is asset-light family businesses that display a higher profitability, but a lower valuation. In the F\&B industry being asset light is positive both 
in terms of ROA and Tobin's Q for family businesses. Finally, we show that results hold if studying the disposal of fixed assets instead of asset levels and accounting for the Global Financial Crisis.

These findings yield interesting and timely implications for two major reasons. First, in the case of Western Europe we observe marked differences in asset-levels depending on the law type of the country companies are incorporated in. Brexit may, therefore, have a twofold effect on the use of assets in the hospitality industry as it should close the gap of the UK model towards a US business model and at the same time homogenize the Continental European model. In the Anglo-Saxon model the asset-light approach is already omnipresent and especially the dynamics of asset reductions and disposals is more rapid. One could thus expect a reinforcement of the asset-light model in the United Kingdom, while the opposite effect may materialize in the European Union. Second, the European context can easily be extended to Asian markets on which a variety of family companies operate, but evolve at a much faster pace. This requires them to either have or be able to access considerable financing capacities (if like in Europe the goal is to remain owner of the properties) or to choose a hybrid approach (an "asset-right" approach à la Accor). It will be interesting to see the impact of their decisions on the financial performance in the future knowing that with time a slowdown in growth will operate and the outcome of the expansionary decisions taken today will materialize. 


\section{REFERENCES}

Anderson, R. C., Duru, A., \& Reeb, D. M. (2012). Investment Policy in Family Controlled Firms. Journal of Banking \& Finance, 36(6), 1744-1758.

Anderson, R. C., \& Reeb, D. M. (2003). Founding-Family Ownership and Firm Performance: Evidence from the S\&P 500. Journal of Finance, 58(3), 1301-1328.

Andres, C. (2008). Large Shareholders and Firm Performance-an Empirical Examination of Founding-Family Ownership. Journal of Corporate Finance, 14(4), 431-445.

Astrachan, J. H., Klein, S. B., \& Smyrnios, K. X. (2002). The F-Pec Scale of Family Influence: A Proposal for Solving the Family Business Definition Problem1. Family Business Review, 15(1), 45-58.

Barontini, R., \& Caprio, L. (2006). The Effect of Family Control on Firm Value and Performance: Evidence from Continental Europe. European Financial Management, 12(5), 689-723.

Bergen, M., Dutta, S., \& Walker, O. C. (1992). Agency Relationships in Marketing: A Review of the Implications and Applications of Agency and Related Theories. Journal of Marketing, 56(3), 1-24.

Bertrand, M., Mehta, P., \& Mullainathan, S. (2002). Ferreting out Tunneling: An Application to Indian Business Groups. The Quarterly Journal of Economics, 117(1), 121-148.

Black, R., Brown, G., Diaz, J., Gibler, K., \& Grissom, T. (2003). Behavioral Research in Real Estate: A Search for the Boundaries. Journal of Real Estate Practice and Education, 6(1), 85112.

Burkart, M., Panunzi, F., \& Shleifer, A. (2003). Family Firms. Journal of Finance, 58(5), 21672201. 
Carney, R. W., \& Child, T. B. (2013). Changes to the Ownership and Control of East Asian Corporations between 1996 and 2008: The Primacy of Politics. Journal of Financial Economics, 107(2), 494-513.

Chen, G., Firth, M., \& Xu, L. (2009). Does the Type of Ownership Control Matter? Evidence from China’s Listed Companies. Journal of Banking \& Finance, 33(1), 171-181.

Chen, M.-H., Kim, W. G., \& Chen, C.-Y. (2007). An Investigation of the Mean Reversion of Hospitality Stock Prices Towards Their Fundamental Values: The Case of Taiwan. International Journal of Hospitality Management, 26(2), 453-467.

Cho, M.-H. (1998). Ownership Structure, Investment, and the Corporate Value: An Empirical Analysis. Journal of Financial Economics, 47(1), 103-121.

Chrisman, J. J., Chua, J. H., \& Litz, R. (2003a). A Unified Systems Perspective of Family Firm Performance: An Extension and Integration. Journal of Business Venturing, 18(4), 467-472.

Chrisman, J. J., Chua, J. H., \& Sharma, P. (2005). Trends and Directions in the Development of a Strategic Management Theory of the Family Firm. Entrepreneurship Theory and Practice, 29(5), 555-576.

Chrisman, J. J., Chua, J. H., \& Steier, L. P. (2003b). An Introduction to Theories of Family Business. Journal of Business Venturing, 18, 441-448.

Chua, J. H., Chrisman, J. J., \& Steier, L. P. (2003). Extending the Theoretical Horizons of Family Business Research. Entrepreneurship Theory and Practice, 27(4), 331-338.

Claessens, S., Djankov, S., \& Lang, L. H. (2000). The Separation of Ownership and Control in East Asian Corporations. Journal of Financial Economics, 58(1), 81-112.

Daily, C. M., \& Dollinger, M. J. (1991). Family Firms Are Different. Review of Business, 13(1, 2), 3-5.

Dyck, A., \& Zingales, L. (2004). Private Benefits of Control: An International Comparison. Journal of Finance, 59(2), 537-600. 
Edmans, A. (2009). Blockholder Trading, Market Efficiency, and Managerial Myopia. Journal of Finance, 64(6), 2481-2513.

Faccio, M., Lang, L. H., \& Young, L. (2001). Dividends and Expropriation. American Economic Review, 91(1), 54-78.

Fahlenbrach, R. (2009). Founder-Ceos, Investment Decisions, and Stock Market Performance. Journal of Financial and Quantitative Analysis, 44(2), 439-466.

Fama, E. F., \& Jensen, M. C. (1985). Organizational Forms and Investment Decisions. Journal of Financial Economics, 14(1), 101-119.

Feldman, E. R., Amit, R. R., \& Villalonga, B. (2016). Corporate Divestitures and Family Control. Strategic Management Journal, 37(3), 429-446.

Gompers, P., \& Lerner, J. (2000). The Determinants of Corporate Venture Capital Success: Organizational Structure, Incentives, and Complementarities. In R. Morck (Ed.), Concentrated Corporate Ownership (pp. 17-54). Chicago: University of Chicago Press.

Gonzalez, M., Molina, C. A., Pablo, E., \& Rosso, J. W. (2017). The Effect of Ownership Concentration and Composition on Dividends: Evidence from Latin America. Emerging Markets Review, 30, 1-18.

Gu, Z., \& Kim, Y. K. (2001). Managerial Stock Holdings and Firm Performance: Empirical Evidence from the Restaurant Industry. International Journal of Hospitality \& Tourism Administration, 2(1), 49-65.

Gu, Z., \& Qian, Y. (1999). Hotel Managerial Ownership and Firm Performance: An Empirical Investigation. Tourism and Hospitality Research, 1(2), 145-154.

Habbershon, T. G., Williams, M., \& MacMillan, I. C. (2003). A Unified Systems Perspective of Family Firm Performance. Journal of Business Venturing, 18(4), 451-465. 
Im, J., \& Chung, Y. (2017). The Effects of Insider Ownership and Board Composition on Firm Performance in the Restaurant Industry. The Journal of Hospitality Financial Management, 25(1), 4-16.

Isakov, D., \& Weisskopf, J.-P. (2014). Are Founding Families Special Blockholders? An Investigation of Controlling Shareholder Influence on Firm Performance. Journal of Banking \& Finance, 41, 1-16.

Jarrell, G., \& Lehn, K. (1985). Institutional Ownership, Tender Offers and Long-Term Investment. Securities Exchange Commission. New York.

Jensen, M. C. (1986). Agency Cost of Free Cash Flow, Corporate Finance, and Takeovers. American Economic Review, 76(2), 323-329.

Jensen, M. C., \& Meckling, W. H. (1976). Theory of the Firm: Managerial Behavior, Agency Costs and Ownership Structure. Journal of Financial Economics, 3(4), 305-360.

Kim, A., Dalbor, M. C., \& Feinstein, A. H. (2007). An Examination of Cost Management Behavior in Small Restaurant Firms. International Journal of Hospitality Management, 26(2), 435-452.

Kim, H. S., \& Jang, S. (2018). Does Hotel Ownership Structure Influence Capital Expenditures? Cornell Hospitality Quarterly, 59(4), 325-338.

King, M. R., \& Santor, E. (2008). Family Values: Ownership Structure, Performance and Capital Structure of Canadian Firms. Journal of Banking \& Finance, 32, 2423-2432.

La Porta, R., Lopez-de-Silanes, F., Shleifer, A., \& Vishny, R. (2002). Investor Protection and Corporate Valuation. Journal of Finance, 57(3), 1147-1170.

La Porta, R., Lopez-de-Silanes, F., Shleifer, A., \& Vishny, R. W. (1998). Law and Finance. Journal of Political Economy, 106(6), 1113-1155.

La Porta, R., Lopez-de-Silanes, F., \& Shleifer, A. (1999). Corporate Ownership around the World. Journal of Finance, 54(2), 471-517. 
Lee, P. M., \& O'Neill, H. M. (2003). Ownership Structures and R\&D Investments of US and Japanese Firms: Agency and Stewardship Perspectives. Academy of Management Journal, 46(2), 212-225.

Lins, K. V., Volpin, P., \& Wagner, H. F. (2013). Does Family Control Matter? International Evidence from the 2008-2009 Financial Crisis. The Review of Financial Studies, 26(10), 25832619.

Maury, B. (2006). Family Ownership and Firm Performance: Empirical Evidence from Western European Corporations. Journal of Corporate Finance, 12(2), 321-341.

Nguyen, P., Rahman, N., \& Zhao, R. (2013). Ownership Structure and Divestiture Decisions: Evidence from Australian Firms. International Review of Financial Analysis, 30, 170-181.

Park, K., \& Jang, S. S. (2010). Insider Ownership and Firm Performance: An Examination of Restaurant Firms. International Journal of Hospitality Management, 29(3), 448-458.

Parrino, R. (1997). Spinoffs and Wealth Transfers: The Marriott Case. Journal of Financial Economics, 43(2), 241-274.

Pérez-González, F. (2006). Inherited Control and Firm Performance. American Economic Review, 96(5), 1559-1588.

Porter, M. E. (1991). Capital Disadvantage: America's Failing Capital Investment System. Harvard Business Review, 70(5), 65-82.

Praet, A. (2013). Family Firms and the Divestment Decision: An Agency Perspective. Journal of Family Business Strategy, 4(1), 34-41.

Salzman, D., \& Zwinkels, R. (2013). Behavioural Real Estate. Retrieved from Amsterdam:

Schulze, W. S., \& Gedajlovic, E. R. (2010). Whither Family Business? Journal of Management Studies, 47(2), 191-204.

Sharma, P., Chrisman, J. J., \& Gersick, K. E. (2012). 25 Years of Family Business Review: Reflections on the Past and Perspectives for the Future. Family Business Review, 25(1), 5-15. 
Sohn, J., Tang, C.-H. H., \& Jang, S. S. (2013). Does the Asset-Light and Fee-Oriented Strategy Create Value? International Journal of Hospitality Management, 32, 270-277.

Sraer, D., \& Thesmar, D. (2007). Performance and Behavior of Family Firms: Evidence from the French Stock Market. Journal of the European Economic Association, 5(4), 709-751.

Stein, J. C. (1988). Takeover Threats and Managerial Myopia. Journal of Political Economy, 96(1), 61-80.

Thomsen, S., \& Pedersen, T. (1998). Industry and Ownership Structure. International Review of Law and Economics, 18(4), 385-402.

Thomsen, S., \& Pedersen, T. (2000). Ownership Structure and Economic Performance in the Largest European Companies. Strategic Management Journal, 21(6), 689-705.

Thurow, L. C. (1992). Head to Head: The Coming Economic Battle among Japan, Europe, and America. New York: Warner Books.

Tsai, H., \& Gu, Z. (2007a). Institutional Ownership and Firm Performance: Empirical Evidence from US-Based Publicly Traded Restaurant Firms. Journal of Hospitality \& Tourism Research, 31(1), 19-38.

Tsai, H., \& Gu, Z. (2007b). The Relationship between Institutional Ownership and Casino Firm Performance. International Journal of Hospitality Management, 26(3), 517-530.

Tsai, H., Pan, S., \& Lee, J. (2011). Recent Research in Hospitality Financial Management. International Journal of Contemporary Hospitality Management, 23(7), 941-971.

Villalonga, B., \& Amit, R. (2006). How Do Family Ownership, Control and Management Affect Firm Value? Journal of Financial Economics, 80(2), 385-417.

Wahal, S., \& McConnell, J. J. (2000). Do Institutional Investors Exacerbate Managerial Myopia? Journal of Corporate Finance, 6(3), 307-329.

Yuan, M., Deng, Z., Song, Z., \& Tang, Y. (2005). A Review of the Ownership Structure and Corporate Performance. China-USA Business Review, 4(1), 49-54. 
Figure 1

Distribution of asset intensity by hospitality sub-sector and ownership
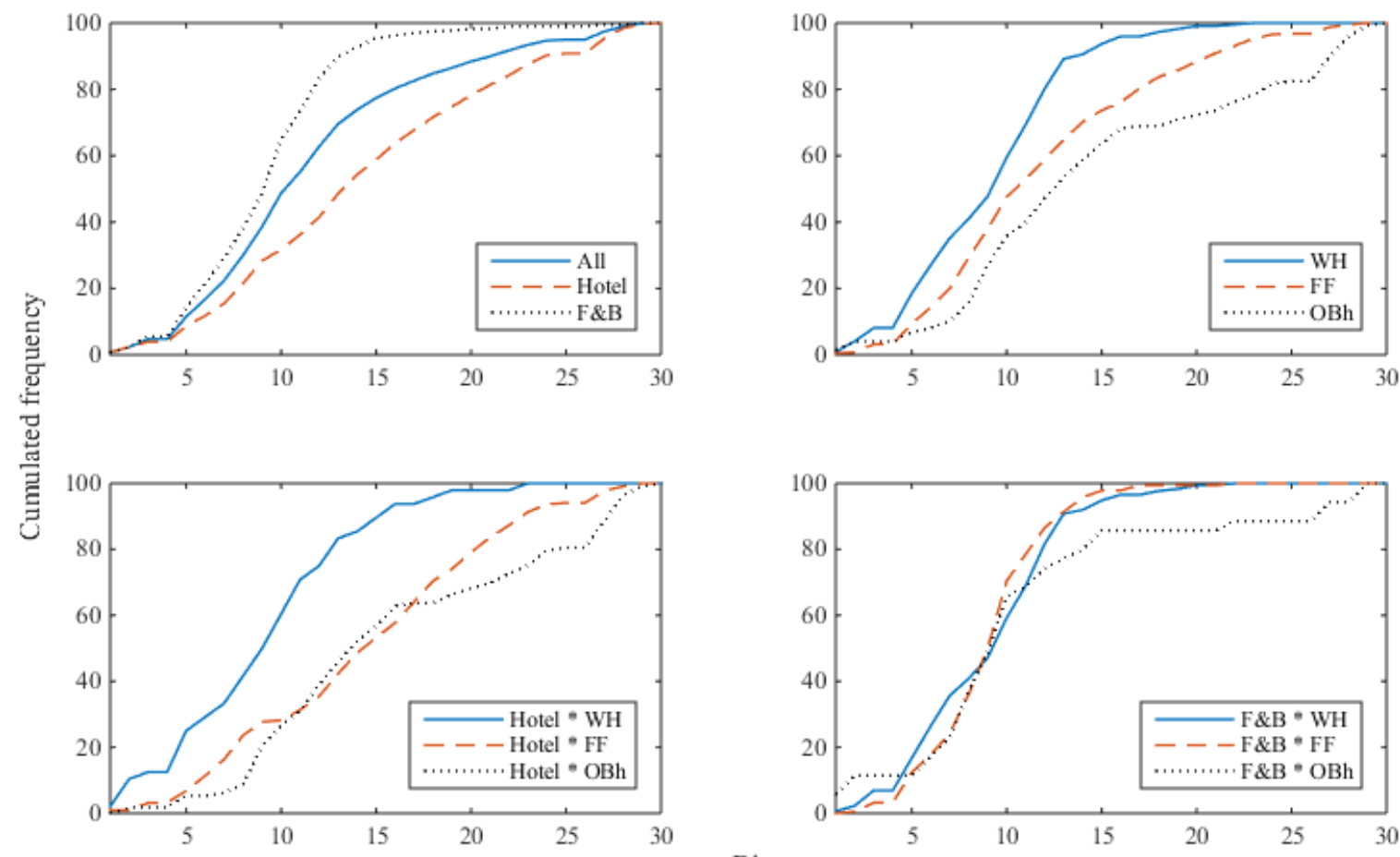

Bin 
Table 1

Descriptive statistics by hospitality sub-sector and ownership

\begin{tabular}{|c|c|c|c|c|c|c|c|c|c|c|c|c|c|}
\hline & \multirow{2}{*}{$\begin{array}{l}\text { All } \\
\text { All }\end{array}$} & \multicolumn{6}{|c|}{ Hotels } & \multicolumn{6}{|c|}{ F\&B } \\
\hline & & All & $\begin{array}{c}\text { Widely- } \\
\text { held }\end{array}$ & Family & Difference & $\begin{array}{c}\text { Other } \\
\text { blockholder }\end{array}$ & Difference & All & $\begin{array}{c}\text { Widely- } \\
\text { held }\end{array}$ & Family & Difference & $\begin{array}{c}\text { Other } \\
\text { blockholder }\end{array}$ & Difference \\
\hline \multirow[t]{2}{*}{ Depreciation / Sales } & 6.26 & 8.02 & 4.51 & 8.10 & $3.60^{* * *}$ & 9.36 & $4.85^{* * *}$ & 4.55 & 4.46 & 4.38 & -0.08 & 5.90 & $1.44^{* *}$ \\
\hline & 4.26 & 4.87 & 3.00 & 4.50 & & 5.48 & & 2.63 & 2.51 & 2.01 & & 4.93 & \\
\hline \multirow[t]{2}{*}{ PP\&E Disposals / Sales } & 4.97 & 6.05 & 16.35 & 4.03 & $-12.32 * * *$ & 3.73 & $-12.62 * * *$ & 4.34 & 6.16 & 2.85 & $-3.31^{* * *}$ & 2.95 & $-3.21 *$ \\
\hline & 8.65 & 10.02 & 14.73 & 8.00 & & 5.37 & & 7.68 & 8.88 & 6.32 & & 5.68 & \\
\hline \multirow[t]{2}{*}{ ROA } & 5.48 & 3.95 & 7.89 & 3.64 & $-4.25 * * *$ & 2.89 & $-5.01^{* * *}$ & 6.95 & 6.80 & 8.04 & $1.24^{*}$ & 1.93 & $-4.86 * * *$ \\
\hline & 5.92 & 4.90 & 7.03 & 4.52 & & 3.55 & & 6.44 & 6.42 & 6.00 & & 6.52 & \\
\hline \multirow[t]{2}{*}{ Tobin's Q } & 1.17 & 1.01 & 1.37 & 0.97 & $-0.40 * * *$ & 0.92 & $-0.45 * * *$ & 1.33 & 1.30 & 1.43 & 0.13 & 0.91 & $-0.39 * * *$ \\
\hline & 0.74 & 0.62 & 0.84 & 0.65 & & 0.35 & & 0.80 & 0.83 & 0.81 & & 0.35 & \\
\hline \multirow[t]{2}{*}{ Ln(total assets) } & 12.81 & 12.69 & 13.86 & 12.22 & $-1.64 * * *$ & 13.09 & $-0.78^{* * *}$ & 12.93 & 13.64 & 12.36 & $-1.28 * * *$ & 12.48 & $-1.16^{* * *}$ \\
\hline & 1.83 & 1.52 & 1.72 & 1.25 & & 1.53 & & 2.08 & 2.03 & 2.03 & & 1.42 & \\
\hline \multirow[t]{2}{*}{ Debt / Capital Employed } & 42.47 & 39.94 & 45.87 & 37.20 & $-8.67 * * *$ & 42.75 & -3.12 & 45.11 & 47.65 & 40.77 & $-6.88 * * *$ & 52.99 & 5.34 \\
\hline & 19.90 & 19.14 & 23.25 & 17.91 & & 18.78 & & 20.35 & 19.28 & 21.45 & & 15.55 & \\
\hline \multirow[t]{2}{*}{ Dividend Payout } & 48.34 & 48.22 & 52.93 & 46.82 & -6.10 & 47.40 & -5.53 & 48.42 & 55.68 & 41.00 & $-14.68 * * *$ & 52.29 & -3.39 \\
\hline & 26.88 & 28.90 & 32.09 & 26.87 & & 31.00 & & 25.47 & 25.16 & 23.20 & & 30.01 & \\
\hline \multirow[t]{2}{*}{ Growth (1y) } & 9.32 & 7.43 & 13.75 & 5.31 & $-8.44 * * *$ & 8.84 & -4.91 & 11.11 & 11.01 & 12.34 & 1.33 & 5.15 & $-5.86 *$ \\
\hline & 17.92 & 18.85 & 26.13 & 15.42 & & 20.62 & & 16.83 & 17.85 & 16.02 & & 14.86 & \\
\hline
\end{tabular}

***, **, * show significance at $1 \%, 5 \%, 10 \%$ levels, respectively. 
Table 2

Relation between ownership and asset intensity (depreciations / sales)

\begin{tabular}{|c|c|c|c|c|c|c|}
\hline & \multicolumn{2}{|c|}{ Hotels } & \multicolumn{2}{|c|}{ F\&B } & \multicolumn{2}{|c|}{ Hospitality } \\
\hline & (1) & (2) & (1) & (2) & (1) & (2) \\
\hline \multirow[t]{2}{*}{$\overline{\text { Family Firm }}$} & $3.801 * * *$ & $3.164^{*}$ & 0.373 & 0.366 & 1.234 & 0.964 \\
\hline & (2.435) & (1.947) & (0.695) & $(0.645)$ & (1.632) & (1.443) \\
\hline \multirow[t]{2}{*}{ Family stake > 50\% } & & 0.745 & & 0.022 & & 0.512 \\
\hline & & $(0.565)$ & & $(0.042)$ & & $(0.686)$ \\
\hline \multirow[t]{2}{*}{ Other blockholder } & $4.913 * * *$ & $4.878 * * *$ & $1.932 * *$ & $1.934^{* *}$ & $2.822 * * *$ & $2.902 * * *$ \\
\hline & $(2.736)$ & (2.733) & $(2.003)$ & $(2.005)$ & $(2.384)$ & (2.474) \\
\hline \multirow[t]{2}{*}{ F\&B } & & & & & $-0.736^{*}$ & -0.716 \\
\hline & & & & & $(-1.683)$ & $(-1.614)$ \\
\hline \multirow[t]{2}{*}{ Constant } & $5.496 * * *$ & $5.5 * * *$ & $4.886 * * *$ & $4.885 * * *$ & $7.389 * * *$ & $7.300 * * *$ \\
\hline & (4.378) & $(4.399)$ & (8.329) & (8.337) & (7.880) & (7.879) \\
\hline Law FE & Yes & Yes & Yes & Yes & Yes & Yes \\
\hline Year FE & Yes & Yes & Yes & Yes & Yes & Yes \\
\hline Observations & 381 & 381 & 395 & 395 & 776 & 776 \\
\hline R-squared & 0.16 & 0.16 & 0.09 & 0.09 & 0.23 & 0.23 \\
\hline
\end{tabular}

T-stats are in parentheses and calculated with clustered-robust standard errors.

$* * *, * *, *$ show significance at 1\%,5\%,10\% levels, respectively. 
Table 3

Relation between ownership and financial performance

\begin{tabular}{|c|c|c|c|c|c|c|c|c|c|c|c|c|}
\hline & \multicolumn{4}{|c|}{ Hotels } & \multicolumn{4}{|c|}{ F\&B } & \multicolumn{4}{|c|}{ Hospitality } \\
\hline & \multicolumn{2}{|c|}{ ROA } & \multicolumn{2}{|c|}{ Tobin's Q } & \multicolumn{2}{|c|}{ ROA } & \multicolumn{2}{|c|}{ Tobin's Q } & \multicolumn{2}{|c|}{ ROA } & \multicolumn{2}{|c|}{ Tobin's Q } \\
\hline & $(1)$ & $(2)$ & $(1)$ & $(2)$ & $(1)$ & $(2)$ & $(1)$ & (2) & $(1)$ & $(2)$ & $(1)$ & $(2)$ \\
\hline Family Firm & $\begin{array}{l}-4.461^{*} \\
(-1.918) \\
\end{array}$ & $\begin{array}{l}-3.899^{*} \\
(-1.704) \\
\end{array}$ & $\begin{array}{l}-0.595^{*} \\
(-1.676)\end{array}$ & $\begin{array}{r}-0.506 \\
(-1.238) \\
\end{array}$ & $\begin{array}{r}1.121 \\
(0.863) \\
\end{array}$ & $\begin{array}{r}1.443 \\
(1.085) \\
\end{array}$ & $\begin{array}{l}0.286^{*} \\
(1.747) \\
\end{array}$ & $\begin{array}{l}0.292 * \\
(1.684) \\
\end{array}$ & $\begin{array}{r}-0.564 \\
(-0.478) \\
\end{array}$ & $\begin{array}{r}0.279 \\
(0.235) \\
\end{array}$ & $\begin{array}{r}-0.036 \\
(-0.237) \\
\end{array}$ & $\begin{array}{r}0.111 \\
(0.674) \\
\end{array}$ \\
\hline Family stake $>50 \%$ & & $\begin{array}{r}-0.656 \\
(-0.667) \\
\end{array}$ & & $\begin{array}{r}-0.104 \\
(-0.386) \\
\end{array}$ & & $\begin{array}{r}-0.961 \\
(-0.522) \\
\end{array}$ & & $\begin{array}{r}-0.019 \\
(-0.098) \\
\end{array}$ & & $\begin{array}{r}-1.600 \\
(-1.336)\end{array}$ & & $\begin{array}{l}-0.279 * \\
(-1.774)\end{array}$ \\
\hline Other blockholder & $\begin{array}{r}-5.108^{* *} \\
(-2.110) \\
\end{array}$ & $\begin{array}{r}-5.077^{* *} \\
(-2.108) \\
\end{array}$ & $\begin{array}{l}-0.644^{*} \\
(-1.802)\end{array}$ & $\begin{array}{l}-0.639 * \\
(-1.800)\end{array}$ & $\begin{array}{r}-5.253 * * * \\
(-2.966) \\
\end{array}$ & $\begin{array}{r}-5.344^{* * * *} \\
(-2.972) \\
\end{array}$ & $\begin{array}{r}-0.235 \\
(-1.500) \\
\end{array}$ & $\begin{array}{r}-0.237 \\
(-1.467)\end{array}$ & $\begin{array}{r}-3.128^{* *} \\
(-2.255) \\
\end{array}$ & $\begin{array}{r}-3.379 * * * \\
(-2.408) \\
\end{array}$ & $\begin{array}{r}-0.258 \\
(-1.418) \\
\end{array}$ & $\begin{array}{r}-0.302 \\
(-1.621) \\
\end{array}$ \\
\hline$F \& B$ & & & & & & & & & $\begin{array}{r}-0.022 \\
(-0.052) \\
\end{array}$ & $\begin{array}{r}-0.086 \\
(-0.195)\end{array}$ & $\begin{array}{l}0.091^{*} \\
(1.885)\end{array}$ & $\begin{array}{r}0.08 \\
(1.609) \\
\end{array}$ \\
\hline Constant & $\begin{array}{r}7.344^{* * *} \\
(3.833) \\
\end{array}$ & $\begin{array}{r}7.340^{* * *} \\
(3.834) \\
\end{array}$ & $\begin{array}{r}1.123 * * * \\
(3.884) \\
\end{array}$ & $\begin{array}{r}1.123 * * * \\
(3.882) \\
\end{array}$ & $\begin{array}{r}6.760 * * * \\
(5.938) \\
\end{array}$ & $\begin{array}{r}6.800^{* * *} \\
(5.88) \\
\end{array}$ & $\begin{array}{r}1.165^{* * *} \\
(8.286) \\
\end{array}$ & $\begin{array}{r}1.166 * * * \\
(8.179) \\
\end{array}$ & $\begin{array}{r}5.206^{* * *} \\
(3.848) \\
\end{array}$ & $\begin{array}{r}5.485^{* * *} \\
(3.846) \\
\end{array}$ & $\begin{array}{r}0.988^{* * *} \\
(6.111) \\
\end{array}$ & $\begin{array}{r}1.036^{* * * *} \\
(6.225) \\
\end{array}$ \\
\hline Law FE & Yes & Yes & Yes & Yes & Yes & Yes & Yes & Yes & Yes & Yes & Yes & Yes \\
\hline Year FE & Yes & Yes & Yes & Yes & Yes & Yes & Yes & Yes & Yes & Yes & Yes & Yes \\
\hline Observations & 381 & 381 & 381 & 381 & 395 & 395 & 395 & 395 & 776 & 776 & 776 & 7776 \\
\hline R-squared & 0.20 & 0.20 & 0.18 & 0.18 & 0.09 & 0.09 & 0.17 & 0.17 & 0.12 & 0.13 & 0.12 & 0.13 \\
\hline
\end{tabular}

T-stats are in parentheses and calculated with clustered-robust standard errors.

$* * *, * *, *$ show significance at $1 \%, 5 \%, 10 \%$ levels, respectively. 
Table 4

Relation between ownership, asset structure and financial performance

\begin{tabular}{|c|c|c|c|c|c|c|c|c|c|c|c|c|}
\hline & \multicolumn{4}{|c|}{ Hotels } & \multicolumn{4}{|c|}{ F\&B } & \multicolumn{4}{|c|}{ Hospitality } \\
\hline & \multicolumn{2}{|c|}{ ROA } & \multicolumn{2}{|c|}{ Tobin's Q } & \multicolumn{2}{|c|}{ ROA } & \multicolumn{2}{|c|}{ Tobin's Q } & \multicolumn{2}{|c|}{ ROA } & \multicolumn{2}{|c|}{ Tobin's Q } \\
\hline & $(1)$ & $(2)$ & $(1)$ & $(2)$ & $(1)$ & $(2)$ & $(1)$ & (2) & $(1)$ & $(2)$ & $(1)$ & $(2)$ \\
\hline Family Firm & $\begin{array}{r}-3.888 \\
(-1.618) \\
\end{array}$ & $\begin{array}{r}-3.428 \\
(-1.445) \\
\end{array}$ & $\begin{array}{r}-0.727^{* *} \\
(-2.105)\end{array}$ & $\begin{array}{l}-0.617 \\
(-1.62)\end{array}$ & $\begin{array}{r}1.441 \\
(1.096)\end{array}$ & $\begin{array}{r}1.757 \\
(1.301)\end{array}$ & $\begin{array}{l}0.303^{*} \\
(1.876)\end{array}$ & $\begin{array}{l}0.309^{*} \\
(1.795)\end{array}$ & $\begin{array}{r}-0.099 \\
(-0.086)\end{array}$ & $\begin{array}{r}0.637 \\
(0.546)\end{array}$ & $\begin{array}{r}-0.052 \\
(-0.345)\end{array}$ & $\begin{array}{r}0.097 \\
(0.596)\end{array}$ \\
\hline Family stake $>50 \%$ & & $\begin{array}{r}-0.545 \\
(-0.535) \\
\end{array}$ & & $\begin{array}{r}-0.130 \\
(-0.521) \\
\end{array}$ & & $\begin{array}{r}-0.942 \\
(-0.573) \\
\end{array}$ & & $\begin{array}{r}-0.018 \\
(-0.095) \\
\end{array}$ & & $\begin{array}{r}-1.409 \\
(-1.247) \\
\end{array}$ & & $\begin{array}{l}-0.287^{*} \\
(-1.840)\end{array}$ \\
\hline Other blockholder & $\begin{array}{l}-4.368^{*} \\
(-1.795) \\
\end{array}$ & $\begin{array}{l}-4.350^{*} \\
(-1.793) \\
\end{array}$ & $\begin{array}{r}-0.815^{* *} \\
(-2.287) \\
\end{array}$ & $\begin{array}{l}-0.81^{* *} \\
(-2.296) \\
\end{array}$ & $\begin{array}{r}-3.594 * * \\
(-1.975) \\
\end{array}$ & $\begin{array}{r}-3.684^{* *} \\
(-2.020) \\
\end{array}$ & $\begin{array}{r}-0.148 \\
(-0.890) \\
\end{array}$ & $\begin{array}{r}-0.150 \\
(-0.891) \\
\end{array}$ & $\begin{array}{r}-2.064 \\
(-1.588) \\
\end{array}$ & $\begin{array}{l}-2.300^{*} \\
(-1.739) \\
\end{array}$ & $\begin{array}{l}-0.295^{*} \\
(-1.676) \\
\end{array}$ & $\begin{array}{l}-0.343^{*} \\
(-1.908) \\
\end{array}$ \\
\hline Depreciation/Sales & $\begin{array}{r}-0.151 \\
(-1.521) \\
\end{array}$ & $\begin{array}{r}-0.149 \\
(-1.493) \\
\end{array}$ & $\begin{array}{r}0.035^{* * *} \\
(3.403) \\
\end{array}$ & $\begin{array}{r}0.035^{* * *} \\
(3.403) \\
\end{array}$ & $\begin{array}{r}-0.859 * * * \\
(-3.520) \\
\end{array}$ & $\begin{array}{r}-0.858^{* * *} \\
(-3.510) \\
\end{array}$ & $\begin{array}{r}-0.045 \\
(-1.041) \\
\end{array}$ & $\begin{array}{r}-0.045 \\
(-1.041) \\
\end{array}$ & $\begin{array}{r}-0.377 * * * \\
(-3.489) \\
\end{array}$ & $\begin{array}{r}-0.372 * * * \\
(-3.405) \\
\end{array}$ & $\begin{array}{r}0.013 \\
(0.903) \\
\end{array}$ & $\begin{array}{r}0.014 \\
(1.017) \\
\end{array}$ \\
\hline$F \& B$ & & & & & & & & & $\begin{array}{r}-0.300 \\
(-0.618) \\
\end{array}$ & $\begin{array}{r}-0.352 \\
(-0.721) \\
\end{array}$ & $\begin{array}{r}0.1^{* *} \\
(2.068)\end{array}$ & $\begin{array}{r}0.09 * \\
(1.789) \\
\end{array}$ \\
\hline Constant & $\begin{array}{r}8.171^{* * *} \\
(3.771) \\
\end{array}$ & $\begin{array}{r}8.159 * * * \\
(3.766) \\
\end{array}$ & $\begin{array}{r}0.932 * * * \\
(3.278) \\
\end{array}$ & $\begin{array}{r}0.929 * * * \\
(3.268) \\
\end{array}$ & $\begin{array}{r}10.955^{* * *} \\
(6.151) \\
\end{array}$ & $\begin{array}{r}10.993^{* * *} \\
(6.182) \\
\end{array}$ & $\begin{array}{r}1.385^{* * *} \\
(4.401) \\
\end{array}$ & $\begin{array}{r}1.386^{* * * *} \\
(4.375) \\
\end{array}$ & $\begin{array}{r}7.993^{* * *} \\
(4.948) \\
\end{array}$ & $\begin{array}{r}8.197 * * * \\
(4.980) \\
\end{array}$ & $\begin{array}{r}0.892 * * * \\
(4.134) \\
\end{array}$ & $\begin{array}{r}0.933 * * * \\
(4.299) \\
\end{array}$ \\
\hline Law FE & Yes & Yes & Yes & Yes & Yes & Yes & Yes & Yes & Yes & Yes & Yes & Yes \\
\hline Year FE & Yes & Yes & Yes & Yes & Yes & Yes & Yes & Yes & Yes & Yes & Yes & Yes \\
\hline Observations & 381 & 381 & 381 & 381 & 395 & 395 & 395 & 395 & 776 & 776 & 776 & 7776 \\
\hline R-squared & 0.22 & 0.22 & 0.24 & 0.24 & 0.20 & 0.20 & 0.19 & 0.19 & 0.18 & 0.19 & 0.12 & 0.14 \\
\hline
\end{tabular}

T-stats are in parentheses and calculated with clustered-robust standard errors.

$* * *, * *, *$ show significance at $1 \%, 5 \%, 10 \%$ levels, respectively. 
Table 5

Interaction between ownership and asset structure

\begin{tabular}{|c|c|c|c|c|c|c|c|c|c|c|c|c|}
\hline & \multicolumn{4}{|c|}{ Hotels } & \multicolumn{4}{|c|}{ F\&B } & \multicolumn{4}{|c|}{ Hospitality } \\
\hline & \multicolumn{2}{|c|}{$\overline{\text { ROA }}$} & \multicolumn{2}{|c|}{ Tobin's Q } & \multicolumn{2}{|c|}{ 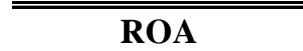 } & \multicolumn{2}{|c|}{ "Tobin's Q } & \multicolumn{2}{|c|}{ 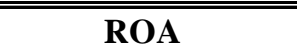 } & \multicolumn{2}{|c|}{ Tobin's Q } \\
\hline & (1) & (2) & (1) & $(2)$ & $(1)$ & $(2)$ & $(1)$ & $(2)$ & $(1)$ & $(2)$ & $(1)$ & (2) \\
\hline AH x Family Firm & $\begin{array}{r}-4.641^{* *} \\
(-1.977)\end{array}$ & $\begin{array}{l}-4.080^{*} \\
(-1.714)\end{array}$ & $\begin{array}{r}-0.497 \\
(-1.352) \\
\end{array}$ & $\begin{array}{r}-0.393 \\
(-0.816) \\
\end{array}$ & $\begin{array}{r}-2.181 \\
(-1.382) \\
\end{array}$ & $\begin{array}{l}-2.832 * \\
(-1.677)\end{array}$ & $\begin{array}{r}-0.008 \\
(-0.038) \\
\end{array}$ & $\begin{array}{r}-0.075 \\
(-0.302) \\
\end{array}$ & $\begin{array}{r}-2.646^{* *} \\
(-2.081)\end{array}$ & $\begin{array}{r}-2.985 * * \\
(-2.318)\end{array}$ & $\begin{array}{r}-0.062 \\
(-0.324) \\
\end{array}$ & $\begin{array}{r}-0.028 \\
(-0.113)\end{array}$ \\
\hline AH x Family stake $>50 \%$ & & $\begin{array}{r}-0.654 \\
(-0.528) \\
\end{array}$ & & $\begin{array}{r}-0.122 \\
(-0.324) \\
\end{array}$ & & $\begin{array}{r}1.896 \\
(0.775) \\
\end{array}$ & & $\begin{array}{r}0.200 \\
(0.746) \\
\end{array}$ & & $\begin{array}{r}0.197 \\
(0.178) \\
\end{array}$ & & $\begin{array}{r}-0.104 \\
(-0.448) \\
\end{array}$ \\
\hline AH x Other blockholder & $\begin{array}{r}-5.045 * * \\
(-1.998)\end{array}$ & $\begin{array}{r}-5.023 * * \\
(-1.997)\end{array}$ & $\begin{array}{l}-0.628^{*} \\
(-1.681) \\
\end{array}$ & $\begin{array}{l}-0.624^{*} \\
(-1.680)\end{array}$ & $\begin{array}{r}-10.414 * * * \\
(-3.221)\end{array}$ & $\begin{array}{r}-10.614 * * * \\
(-3.227)\end{array}$ & $\begin{array}{r}-0.247 \\
(-1.116) \\
\end{array}$ & $\begin{array}{r}-0.255 \\
(-1.122) \\
\end{array}$ & $\begin{array}{r}-3.859 * * * \\
(-2.357)\end{array}$ & $\begin{array}{r}-4.145^{* * *} \\
(-2.451)\end{array}$ & $\begin{array}{r}-0.156 \\
(-0.752) \\
\end{array}$ & $\begin{array}{r}-0.210 \\
(-0.979)\end{array}$ \\
\hline AL x Family Firm & $\begin{array}{r}-3.702 \\
(-1.491) \\
\end{array}$ & $\begin{array}{r}-3.182 \\
(-1.372) \\
\end{array}$ & $\begin{array}{r}-0.982 * * * \\
(-2.590)\end{array}$ & $\begin{array}{r}-0.911 * * * \\
(-2.468)\end{array}$ & $\begin{array}{r}2.827^{* *} \\
(2.092)\end{array}$ & $\begin{array}{r}3.643 * * * \\
(3.009) \\
\end{array}$ & $\begin{array}{r}0.441^{* * *} \\
(2.857)\end{array}$ & $\begin{array}{r}0.483 * * * \\
(2.739)\end{array}$ & $\begin{array}{r}1.340 \\
(1.151)\end{array}$ & $\begin{array}{r}2.705^{* * *} \\
(2.494)\end{array}$ & $\begin{array}{r}0.003 \\
(0.019) \\
\end{array}$ & $\begin{array}{r}0.202 \\
(1.128) \\
\end{array}$ \\
\hline AL x Family stake $>50 \%$ & & $\begin{array}{r}-0.616 \\
(-0.481) \\
\end{array}$ & & $\begin{array}{r}-0.082 \\
(-0.605)\end{array}$ & & $\begin{array}{r}-2.164 \\
(-1.052)\end{array}$ & & $\begin{array}{r}-0.108 \\
(-0.541) \\
\end{array}$ & & $\begin{array}{l}-2.748^{*} \\
(-1.762) \\
\end{array}$ & & $\begin{array}{r}-0.402 * * \\
(-1.972)\end{array}$ \\
\hline AL x Other blockholder & $\begin{array}{r}-4.971^{* *} \\
(-2.099)\end{array}$ & $\begin{array}{r}-4.924^{* *} \\
(-2.089)\end{array}$ & $\begin{array}{r}-0.828 * * \\
(-2.288)\end{array}$ & $\begin{array}{r}-0.820 * * \\
(-2.288)\end{array}$ & $\begin{array}{r}-2.300 \\
(-1.289)\end{array}$ & $\begin{array}{l}-2.503 \\
(-1.39)\end{array}$ & $\begin{array}{r}-0.187 \\
(-1.048) \\
\end{array}$ & $\begin{array}{r}-0.198 \\
(-1.074) \\
\end{array}$ & $\begin{array}{r}-2.748 * * \\
(-2.199)\end{array}$ & $\begin{array}{r}-2.915^{* *} \\
(-2.298)\end{array}$ & $\begin{array}{r}-0.417 * * * \\
(-2.568)\end{array}$ & $\begin{array}{r}-0.445 * * * \\
(-2.669)\end{array}$ \\
\hline F\&B & & & & & & & & & $\begin{array}{r}-0.022 \\
(-0.049) \\
\end{array}$ & $\begin{array}{r}-0.09 \\
(-0.201) \\
\end{array}$ & $\begin{array}{r}0.102 * * \\
(2.078)\end{array}$ & $\begin{array}{r}0.09 * \\
(1.735) \\
\end{array}$ \\
\hline Constant & $\begin{array}{r}7.42 * * * \\
(3.863) \\
\end{array}$ & $\begin{array}{r}7.414^{* * *} \\
(3.863) \\
\end{array}$ & $\begin{array}{r}1.088 * * * \\
(3.674)\end{array}$ & $\begin{array}{r}1.086 * * * \\
(3.665) \\
\end{array}$ & $\begin{array}{r}6.954 * * * \\
(6.097) \\
\end{array}$ & $\begin{array}{r}6.885 * * * \\
(6.102)\end{array}$ & $\begin{array}{r}1.177^{* * *} \\
(8.286)\end{array}$ & $\begin{array}{r}1.169 * * * \\
(8.282)\end{array}$ & $\begin{array}{r}6.324 * * * \\
(4.829)\end{array}$ & $\begin{array}{r}6.445^{* * *} \\
(4.691) \\
\end{array}$ & $\begin{array}{r}0.989 * * * \\
(5.563)\end{array}$ & $\begin{array}{r}1.022^{* * *} \\
(5.612) \\
\end{array}$ \\
\hline Law FE & Yes & Yes & Yes & Yes & Yes & Yes & Yes & Yes & Yes & Yes & Yes & Yes \\
\hline Year FE & Yes & Yes & Yes & Yes & Yes & Yes & Yes & Yes & Yes & Yes & Yes & Yes \\
\hline Observations & 381 & 381 & 381 & 381 & 395 & 395 & 395 & 395 & 776 & 776 & 776 & 776 \\
\hline R-squared & 0.20 & 0.20 & 0.24 & 0.24 & 0.17 & 0.18 & 0.20 & 0.20 & 0.17 & 0.19 & 0.12 & 0.14 \\
\hline
\end{tabular}

AH denotes companies with depreciation / sales exceeding the overall median and AL below-median companies.

T-stats are in parentheses and calculated with clustered-robust standard errors.

$* * *, * *, *$ show significance at $1 \%, 5 \%, 10 \%$ levels, respectively. 